\title{
Pengaruh Temuan Audit Dan Tindak Lanjut Hasil Pemeriksaan Terhadap Tingkat Pengungkapan Laporan Keuangan Pada Kementerian
}

\author{
Ghinna Imtinan, David HM Hasibuan \\ Program Studi Akuntansi, Institut Bisnis dan Informatika Kesatuan, Bogor \\ E-Mail : ghinna.imtinan@ibik.ac.id
}

\section{ABSTRACT}

The purpose of this study is to determine the effect of audit findings and follow-up of audit recommendation on the level of disclosure of the ministry's financial statements. The research method used is a quantitative method. The analysis technique is multiple regression analysis. This study uses selected samples of 13 ministries in Indonesia during the observation period. The results of this study indicate that partially or t-test by SPSS test concluded that the audit findings and follow-up of the audit results affect the level of disclosure of the ministry's financial statements. For test results $f$ or simultaneous audit findings and follow-up audit results affect the level of financial statement disclosure. The results of this simultaneous test are in accordance with the theory that the findings found and given recommendations then followed up will increase the disclosure of financial statements.

Keywords: audit finding, audit recommendation, disclosure level of financial statements

\begin{abstract}
ABSTRAK
Tujuan dari penelitian ini adalah untuk mengetahui pengaruh temuan audit dan tindak lanjut hasil pemeriksaan terhadap tingkat pengungkapan laporan keuangan kementerian. Metode penelitian yang digunakan adalah metode kuantitatif. Teknik analisisnya yaitu anaisis regresi berganda. Penelitian ini menggunakan sampel terpilih yaitu 13 kementerian di Indonesia selama periode pengamatan. Pengumpulan data dilakukan dengan cara dokumentasi yaitu mengambil dari internet dan literlatur. Hasil penelitian ini menunjukan hasil bahwa secara parsial atau uji t oleh uji SPSS disimpulkan bahwa temuan audit dan tindak lanjut hasil pemeriksaan berpengaruh terhadap tingkat pengungkapan laporan keuangan kementerian. Untuk hasil uji $\mathrm{f}$ atau secara simultan temuan audit dan tindak lanjut hasil pemeriksaan berpengaruh terhadap tingkat pengungkapan laporan keuangan. Hasil uji simultan ini sesuai dengan teori yang mengatakan bahwa temuan yang ditemukan dan diberikan rekomendasi kemudian di tindaklanjuti akan meningkatkan pengungkapan laporan keuangan.
\end{abstract}

Kata Kunci: Temuan Audit, Tindak Lanjut Hasil Pemeriksaan, Tingkat Pengungkapan Laporan Keuangan

\section{PENDAHULUAN}

Masyarakat saat ini menuntut akuntabilitas publik agar semakin menguat. Pemerintah pusat dan daerah, dituntut juga untuk dapat memenuhi hak-hak publik karena perannya sebagai pemberi informasi. Dalam Pasal 16 ayat 1 Undang-Undang Nomor 15 tahun 2004 tentang Pemeriksaan Pengelolaan dan Tanggung Jawab Keuangan Negara dikatakan bahwa semakin tinggi tingkat pengungkapan laporan keuangan maka semakin

\section{JIAKES}

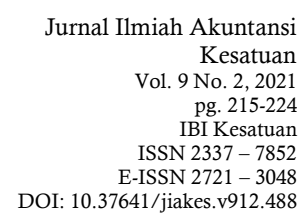
Kesatuan Vol. 9 No. 2, 2021 pg. $215-224$
IBI Kesatuan IBI Kesatuan ISSN $2337-7852$
E-ISSN $2721-3048$ DOI: $10.37641 /$ jiakes.v912.488 
Disclosure Level of baik pula kualitas dari laporan keuangan tersebut sehingga probabilitas opini audit yang Financial

Statement akan diperoleh oleh Pemerintah Pusat maupun daerah pun akan semakin baik pula.

Terkait dengan pengungkapan dalam laporan keuangan, Badan Pemeriksa Keuangan (BPK) menyoroti sejumlah masalah dalam laporan keuangan Kementerian tahun 2018, salah satu catatannya ada pada Kementerian Keuangan (Kemenkeu). Selain dari permasalahan diatas, terdapat kelemahan sistem keuangan negara Indonesia yang terjadi sebelum tahun 2009 dimana sistem tersebut telah terdapat dari Pemerintahan Orde Baru yang sifatnya mendasar.

Buruknya pengelolaan keuangan negara itu sekaligus telah menjadi salah satu faktor penyebab krisis ekonomi Indonesia pada tahun 1997-1998 dan lambatnya pemulihannya hingga saat ini.

Untuk meningkatkan transparansi dan akuntabilitas pengelolaan keuangan negara, Pemerintah era reformasi telah melakukan koreksi secara menyeluruh sistem pembukuan, manajemen maupun pertanggung jawaban keuangan negara yang dipergunakan pada masa Pemerintahan Orde Baru.

Menurut prosedur audit internal pada inspektorat pemerintah pusat/daerah, inspektorat melaporkan setiap hasil audit kepada subyek audit dari pemerintah pusat/daerah dan inspektorat selalu memberikan rekomendasi kepada subyek audit sehingga setiap temuan audit mungkin terpecahkan. Prosedur yang sama juga diterapkan oleh BPK sebagai audit eksternal. BPK umumnya membuat rekomendasi berdasarkan audit temuan untuk menyelesaikan keuangan subjek audit yang bermasalah. (Mahpiansyah, 2016).

Pembetulan setelah proses audit merupakan suatu bentuk tanggung jawab dari Kementerian atas kesalahan dalam pertanggungjawaban keuangan publik. Sehingga dengan adanya pembetulan tersebut maka temuan audit dapat bermanfaat untuk menciptakan akuntabilitas dalam proses audit pemerintahan demi terciptanya akuntabilitas (Liu dan Lin, 2012).

Karena fenomena yang terjadi, maka penulis tertarik untuk meneliti tentang hal-hal yang mempengaruhi tingkat pengungkapan pada laporan keuangan pemerintah. Dalam hal ini peneliti akan mengambil objek Kementerian. Terdapat beberapa faktor yang berpengaruh terhadap tingkat pengungkapan laporan keuangan pemerintah.

\section{METODE}

Populasi yang digunakan dalam penelitian ini adalah Kementerian di Indonesia di Tahun 2016-2018. Penelitian ini menggunakan teknik pengambilan sampel menggunakan purposive sampling yaitu populasi yang akan dijadikan sampel. Jenis penelitian yang digunakan dalam penelitian ini adalah jenis penelitian kuantitatif. Operasional variabel juga diperlukan untuk menentukan jenis dan indikator dari variabelvariabel yang terkait dalam penelitian ini, baik variabel dependen maupun variabel independen.

Jenis data yang digunakan dalam penelitian ini adalah data sekunder. Sumber data tersebut diperoleh dari masing-masing website resmi Kementerian dan Badan Pemeriksa Keuangan Republik Indonesia. Metode pengumpulan data yang digunakan dalam penelitian ini adalah studi pustaka dan dokumentasi.

Penulis melakukan analisis deskriptif terhadap data laporan keuangan Kementerian yang dijadikan sampel dalam penelitian ini sebelum regresi dilakukan dan analisis lebih lanjut terhadap hasil dari regresi tersebut. Dalam pengujian regresi ini, penyusun melakukan uji asumsi klasik.

\section{HASIL DAN PEMBAHASAN \\ Pemilihan Sampel}

Sampel yang digunakan dalam penelitian ini adalah sebanyak 13 Kementerian setiap tahunnya atau berjumlah 39 observasi untuk tiga tahun pengamatan (2016-2018). Sampel yang akan digunakan dalam penelitian ini diambil dengan menggunakan teknik purposive 
sampling yang berarti bahwa sampel akan diambil berdasarkan kriteria-kriteria yang telah ditetapkan (Yulianingtyas, 2010; Rahmayanti, 2018).

Tabel 1. Proses Seleksi Sampel

\begin{tabular}{|l|c|}
\hline \multicolumn{1}{|c|}{ Kriteria } & Total \\
\hline LK Kementerian periode tahun 2016-2018 yang telah diaudit oleh BPK & 34 \\
\hline Kementerian yang berdiri setelah tahun 2016 & - \\
\hline $\begin{array}{l}\text { Kementerian yang tidak memiliki data temuan audit dan tindak lanjut hasil } \\
\text { pemeriksaan dari tahun 2016-2018 }\end{array}$ & $(5)$ \\
\hline $\begin{array}{l}\text { Kementerian yang tidak mengungkapkan laporan keuangan di website } \\
\text { resmi Kementerian tersebut }\end{array}$ & $(16)$ \\
\hline Kementerian yang dijadikan sampel penelitian & 13 \\
\hline Total Sampel Penelitian (2016-2018) & 39 \\
\hline
\end{tabular}

Berikut ini merupakan daftar kementrian yang menjadi sampel dalam penelitian ini:

\begin{tabular}{|c|l|}
\hline No & \multicolumn{1}{|c|}{ Nama Kementerian } \\
\hline 1 & Kementerian Desa, Daerah Tertinggal dan Transmigrasi \\
\hline 2 & Kementerian Hukum dan Hak Asasi Manusia \\
\hline 3 & Kementerian Kelautan dan Perikanan \\
\hline 4 & Kementerian Kesehatan \\
\hline 5 & Kementerian Ketenagakerjaan \\
\hline 6 & Kementerian Keuangan \\
\hline 7 & Kementerian Komunikasi dan Informatika \\
\hline 8 & Kementerian Pekerjaan Umum dan Perumahan Rakyat \\
\hline 9 & Kementerian Perdagangan \\
\hline 10 & Kementerian Perhubungan \\
\hline 11 & Kementerian Pertanian \\
\hline 12 & Kementerian Pemberdayaan Perempuan dan Perlindungan Anak \\
\hline 13 & Kementerian Koornator Bidang Pembangunan Manusia dan Kebudayaan \\
\hline
\end{tabular}
Sumber: Data diolah 2020

\section{Analisis Deksriptif}

Sampel dalam penelitian ini menggunakan 39 Laporan Keuangan Kementerian, dari sampel tersebut diperoleh statistik deskriptif yang mencakup banyaknya data yang diperoleh (n), nilai minimum, nilai maksimum, rata-rata (mean), dan standar deviasi (std. Deviation) atas variabel-variabel dari penelitian. Hasil dari statistik deskriptif disajikan dalam tabel 1.

\section{Tabel 1 Descriptive Statistics}

\begin{tabular}{|l|r|r|r|r|r|}
\hline \multicolumn{1}{|c|}{ Keterangan } & \multicolumn{1}{c|}{$\mathrm{N}$} & Minimum & Maximum & Mean & Std. Deviation \\
\hline $\begin{array}{l}\text { DISC (Tingkat Pengungkapan } \\
\text { Laporan Keuangan) }\end{array}$ & 39 & .5542 & .8193 & .7088 & .05234 \\
\hline FIND (Temuan Audit) & 39 & 6 & 191 & 48.26 & 41.020 \\
\hline $\begin{array}{l}\text { TLHP (Tindak Lanjut Hasil } \\
\text { Pemeriksaan) }\end{array}$ & 39 & .0270 & .9474 & .4809 & .22645 \\
\hline Valid N (listwise) & 39 & & & & \\
\hline
\end{tabular}

Sumber: Output SPSS

Tingkat Pengungkapan Laporan Keuangan - Tabel 1 merupakan hasil statistik deskriptif yang menunjukkan bahwa nilai minimum tingkat pengungkapan Laporan Keuangan Kementerian untuk periode 2016-2018 adalah 55,42\% sedangkan nilai maksimumnya adalah sebesar $81,93 \%$. Nilai rata-rata tingkat pengungkapan Laporan Keuangan Kementerian adalah $70,88 \%$, tingkat pengungkapan pada Kementerian cenderung mengalamikenaikan setiap tahunnya, akan tetapi ada beberapa Kementerian yang mengalami sedikit penurunan karena ada beberapa item yang tidak diungkapkan kembali pada periode berikutnya.
Disclosure Level of

Financial

Statement 
Disclosure Level of

Financial

Statement

$\underline{218}$
Temuan Audit - Berdasarkan pada tabel 4.3 diketahui bahwa rata-rata temuan audit pada Kementerian adalah 48,26 kasus dengan standar deviasi sebesar 41,020. Temuan audit paling sedikit terdapat pada Kementerian Perdagangan dengan temuan sebanyak 6 temuan, sedangkan temuan terbanyak terdapat pada Kementerian Keuangan dengan temuan sebanyak 191 temuan.

Tindak Lanjut Hasil Pemeriksaan - pada tabel 1 menunjukkan bahwa rata-rata tindak lanjut yang dilakukan oleh Kementerian sebesar 48,09\%, sedangkan standar deviasinya adalah sebesar 0,22645 . Tindak lanjut yang dilakukan paling sedikit dilakukan oleh Kementerian Desa, Daerah Tertinggal dan Transmigrasi sebanyak 2,70\% sedangkan paling banyak dilakukan oleh Kementerian Pemberdayaan Perempuan dan Perlindungan Anak sebanyak 94,74\% dari total rekomendasi.

\section{Uji Asumsi Klasik}

Uji asumsi klasik diperlukan untuk mengetahui apakah hasil estimasi regresi yang dilakukan sudah terdistribusi secara normal dan benar-benar bebas dari adanya gejala heteroskedastisitas dan gejala multikolinearitas. Uji normalitas dilakukan untuk menguji apakah dalam model regresi, suatu variabel independen dan dependen ataupun keduanya mempunyai distribusi normal atau tidak. Data dapat dikatakan terdistribusi normal apabila tampilan histogram membentuk pola lonceng, dan pada tampilan Normal Probability Plot dapat terlihat bahwa titik-titik akan mengikuti garis diagonalnya. Sedangkan pada uji statistik dilakukan dengan menggunakan uji One Sample Kolmogorov Smirnov yaitu dengan ketentuan apabila nilai signifikansi diatas 5\% atau 0,05 maka data memiliki distribusi normal. Tampilan histogram atas menunjukkan pola lonceng yang berarti data yang diolah atau digunakan dalam penelitian ini dapat dikatakan terdistribusi normal. Sehingga dapat disimpulkan bahwa data yang digunakan dalam penelitian ini dapat digunakan untuk pengujian selanjutnya.

Hasil uji normalitas dengan normal probability plot menunjukkan bahwa titik-titik menyebar di sekitar garis diagonal dan memiliki arah garis diagonal. Pola penyebaran tersebut menunjukkan bahwa data terdistribusi dengan normal, sehingga dapat disimpulkan bahwa model regresi memenuhi asumsi normalitas dan layak digunakan untuk pengujian selanjutnya. Selain analisis grafik, untuk menguji normalitas pada penelitian ini digunakan uji statistik nonparametrik Kolmogorov-Smirnov (K-S) dengan hasil nilai Asymp. Sig. (2-tailed) adalah 0,820, nilai tersebut lebih besar dari nilai signifikansi 0,05 . Berdasarkan hasil tersebut maka diketahui bahwa data yang diolah terdistribusi secara normal. Hal ini menunjukkan bahwa uji normalitas telah terpenuhi dan data yang digunakan layak untuk dioleh sehingga penelitian dapat dilanjutkan.

Uji autokorelasi bertujuan untuk mengetahui apakah dalam sebuah model regresi linear ada korelasi antar kesalahan penganggu pada periode $t$ dengan kesalahan pada periode t-1(sebelumnya). Pada output Runs Test di atas terlihat bahwa nilai probabilitasnya adalah 0,519 . Untuk menyimpulkan apakah terjadi gejala autokorelasi atau tidak maka nilai test dibandingkan dengan nilai tabel atau nilai probabilitas dibandingkan dengan nilai alphanya. Berdasarkan output tersebut diperoleh nilai probabilitas sebesar 0,519 lebih besar dari pada 0,05, sehingga hipotesis nihil menyatakan nilai residual manyebar secara acak diterima. Dengan demikian maka tidak terjadi gejala autokorelasi.

Uji multikolinearitas bertujuan untuk mengetahui apakah pada model regresi ditemukan adanya korelasi antar variabel independen atau variabel bebas. Untuk menemukan terdapat atau tidaknya multikolinearitas pada model regresi dapat diketahui dari nilai toleransi dan nilai variance inflation factor $(V I F)$. Apabila nilai $V I F<10$ dan nilai tolerance $>0,10$, maka tidak terjadi multikolinearitas. Hasil dari uji multikolinearitas menyatakan bahwa semua variabel independen pada penelitian ini memiliki nilai $V I F<$ 10 , nilai $V I F$ dari setiap variabel independen pada penelitian ini apabila dilihat dari tabel 4.4 adalah nilai VIF untuk temuan audit dan tindak lanjut hasil pemeriksaan masingmasing sebesar 0,982 . Hasil uji multikolinearitas juga menyatakan bahwa setiap variabel independen memiliki nilai tolerance $>0,10$, yaitu nilai tolerance pada variabel temuan audit 
dan tindak lanjut hasil pemeriksaan masing-masing sebesar 1,018. Berdasarkan dari nilai VIF dan tolerance dapat disimpulkan bahwa model regresi pada penelitian ini tidak mengandung multikolinearitas. Uji heteroskedastisitas bertujuan untuk melakukan uji apakah pada sebuah model regresi terjadi ketidaksamaan varian dari residual dalam satu pengamatan ke pengamatan lainnya. Berdasarkan grafik scatterplot terlihat bahwa titiktitik tidak membentuk pola tertentu dan menyebar secara acak serta tersebar baik di atas maupun di bawah angka 0 pada sumbu Y. Dari hasil tersebut dapat disimpulkan bahwa tidak terjadi heteroskedastisitas pada model regresi. Hasil dari uji heteroskedastisitas pada setiap variabel lebih besar dari nilai sig $>0,05$, yaitu variabel temuan audit memiliki nilai sig. sebesar 0,301 dan variabel tindak lanjut hasil pemeriksaan memiliki nilai sig. sebesar 0,082. Dari hasil tersebut dapat disimpulkan bahwa model regresi pada penelitian ini tidak terdapat heteroskedastisitas.

\section{Hasil Analisis Regresi Berganda}

Model analisis regresi berganda digunakan untuk mengetahui pengaruh variabel independen terhadap variabel dependen. Variabel dependen atau variabel yang akan dipengaruhi pada penelitian ini adalah tingkat pengungkapan LK Kementerian di Indonesia. Hasil perhitungan regresi berganda pada penelitian ini disajikan dalam tabel 2 .

Tabel 2 Hasil Analisis Regresi Berganda

\begin{tabular}{|c|c|c|c|c|c|}
\hline \multirow[t]{2}{*}{ Model } & \multicolumn{2}{|c|}{$\begin{array}{l}\text { Unstandardized } \\
\text { Coefficients }\end{array}$} & \multirow{2}{*}{$\begin{array}{c}\text { Standardized } \\
\text { Coefficients } \\
\text { Beta }\end{array}$} & \multirow[t]{2}{*}{$t$} & \multirow[t]{2}{*}{ Sig. } \\
\hline & B & Std. Error & & & \\
\hline (Constant) & .632 & .020 & & 31.807 & .000 \\
\hline FIND (Temuan Audit) & .000 & .000 & .343 & 2.481 & .018 \\
\hline $\begin{array}{l}\text { TLHP (Tindak Lanjut } \\
\text { Hasil Pemeriksaan) }\end{array}$ & .116 & .032 & .500 & 3.612 & .001 \\
\hline
\end{tabular}

a. Dependent Variable: Y

Sumber: Output SPSS diolah 2020

Secara matematis hasil dari analisis regresi berganda pada tabel 4.8 dapat ditulis sebagai berikut.

DISC $=0,632+0,000$ FIND $+0,116$ TLHP

Dari persamaan diatas menunjukkan pengaruh variabel independen (FIND dan TLHP) terhadap variabel dependen (DISC atau tingkat pengungkapan laporan keuangan). Arti dari koefisien regresi tersebut adalah sebagai berikut.

1. Konstanta sebesar 0,632 menyatakan bahwa, apabila variabel bebas atau independen bernilai nol, maka nilai pengungkapan Laporan Keuangan Kementerian di Indonesia adalah sebesar 0,632 .

2. Koefisien FIND sebesar 0,0004 menunjukkan bahwa setiap terdapat penambahan 1 nilai pada FIND, maka akan meningkatkan DISC sebesar 0,0004 .

Koefisien TLHP sebesar 0,116 menunjukkan bahwa setiap terdapat penambahan 1 nilai pada TLHP, maka akan meingkatkan DISC sebesar 0,116.

\section{Hasil Uji Koefisien Determinasi}

Uji koefisien determinasi merupakan pengujian yang bertujuan untuk melihat kemampuan variabel independen di dalam menjelaskan variasi perubahan variabel dependen. Hasil uji koefisien determinasi dalam penelitian ini ditunjukkan pada tabel 4.9 sebagai berikut.

Tabel 3 Hasil Uji Koefisien Determinasi

\begin{tabular}{cc|c|c|c} 
Model & $\mathrm{R}$ & R Square & Adjusted R Square & $\begin{array}{c}\text { Std. Error of the } \\
\text { Estimate }\end{array}$ \\
\hline 1 & $568^{\mathrm{a}}$ & .322 & .285 & .04427 \\
\hline
\end{tabular}

a. Predictors (Constant), X2, X1

b. Dependent Variable: Y

Sumber: Output SPSS diolah 2020

Disclosure Level of

Financial

Statement

219 
Disclosure Level of

Financial

Statement

220
Hasil yang didapatkan pada uji koefisiensi determinasi (Adjusted $R^{2}$ ) adalah sebesar 0,285 atau $28,5 \%$. Pernyataan tersebut menunjukkan bahwa variabel dependen tingkat pengungkapan Laporan Keuangan Kementerian di Indonesia dapat dijelaskan sebesar $28,5 \%$ oleh variabel-variabel independen yang digunakan didalam penelitian ini. Sedangkan sisanya sebesar 71,5\% (100\%-28,5\%) lainnya dapat dijelaskan oleh variabel lain yang tidak digunakan didalam penelitian ini.

\section{Uji Hipotesis}

Untuk mengetahui apakah variabel bebas secara individual mempunyai pengaruh signifikan terhadap variabel terikat maka dilakukan uji $\mathrm{t}$ dengan tingkat signifikansi $\alpha=$ $5 \%$. Hasil perhitungan dari masing-masing variabel dapat dilihat pada tabel 2 . Dari tabel tersebut dapat diuraikan hasil perhitungan dari masing-masing variabel adalah sebagai berikut.

1) Temuan Audit

Berdasarkan perhitungan diperoleh nilai $t_{\text {hitung }}$ sebesar 2,481 dan nilai signifikansi sebesar 0,018 yang berarti bahwa nilai $t_{\text {hitung }}$ lebih besar dari $t_{\text {tabel }}$ dan nilai signifikansi t dari temuan audit lebih kecil daripada nilai signifikansi $\alpha$. Nilai $t_{\text {hitung }}$ sebesar 2,481 sedangkan $t_{\text {tabel }}$ yaitu $t(2,36) ;(0,05)$ di dapat nilai 2,02809 sehingga $t_{\text {hitung }}>t_{\text {tabel }}$ dan nilai signifikansi $\alpha$ adalah $0,018<0,05$, sehingga pernyataan tersebut menggambarkan bahwa $\mathrm{H}_{1}$ diterima, yang berarti bahwa temuan audit berpengaruh positif terhadap pengungkapan Laporan Keuangan Kementerian.

2) Tindak Lanjut Hasil Penelitian

Berdasarkan perhitungan diperoleh nilai $t_{\text {hitung }}$ sebesar 3,612 dan nilai signifikansi sebesar 0,001 yang berarti bahwa nilai $t_{\text {hitung }}$ lebih besar dari $t_{\text {tabel }}$ dan nilai signifikansi $\mathrm{t}$ dari tindak lanjut hasil pemeriksaan lebih kecil daripada nilai signifikansi $\alpha$. Nilai $t_{\text {hitung }}$ sebesar 3,612 sedangkan $t_{\text {tabel }}$ yaitu $t(2,36) ;(0,05)$ di dapat nilai 2,02809 sehingga $t_{\text {hitung }}>t_{\text {tabel }}$ dan nilai signifikansi $\alpha$ adalah $0,001<0,05$, sehingga pernyataan tersebut menggambarkan bahwa $\mathrm{H}_{2}$ diterima, yang berarti bahwa tindak lanjut hasil pemeriksaan berpengaruh positif terhadap pengungkapan Laporan Keuangan Kementerian.

Untuk membuktikan hipotesis yang diajukan dan menjawab rumusan masalah yang ketiga maka dalam penelitian ini digunakan uji $\mathrm{F}$ untuk pengaruh simultan. Dengan menggunakan program SPSS untuk mengetahui apakah temuan audit dan tindak lanjut hasil pemeriksaan secara simultan mempunyai pengaruh signifikan terhadap tingkat pengungkapan laporan keuangan kementerian maka diperoleh hasil uji $\mathrm{F}$ seperti pada tabel berikut.

Tabel 3 Hasil Uji F

\begin{tabular}{ccc|c|c|c|c}
\multicolumn{2}{c}{ Model } & $\begin{array}{c}\text { Sum of } \\
\text { Squares }\end{array}$ & Df & Mean Square & F & Sig. \\
\hline \multirow{2}{*}{1} & Regression & .034 & 2 & .017 & 8.556 & $.001^{\text {b }}$ \\
\cline { 2 - 8 } & Residual & .071 & 36 & .002 & & \\
\cline { 2 - 8 } & Total & .104 & 38 & & & \\
\hline
\end{tabular}

a. Dependent Variable: Y

b. Predictors: (Constant), X1, X2

Sumber: Output SPSS diolah 2020

Dari hasil uji $F$ didapat nilai $F_{\text {hitung }}$ sebesar 8,556 sedangkan $F_{\text {tabel }}$ yaitu $F(2,36) ;(0,05)$ di dapat nilai 3,26 sehingga $F_{\text {hitung }}>F_{\text {tabel }}$ dan signifikansi pada tingkat 0,001 pada taraf $5 \%$ maka $(0,001<0,05)$. Artinya bahwa secara bersama-sama variabel bebas yang terdiri dari temuan audit dan tindak lanjut hasil pemeriksaan berpengaruh secara signifikan terhadap tingkat pengungkapan laporan keuangan. Dan dapat disimpulkan bahwa $\mathrm{H}_{3}$ diterima.

\section{Pembahasan Data Hasil Penelitian}

Pengaruh Temuan Audit terhadap Tingkat Pengungkapan Laporan Keuangan Kementrian. Hasil pengujian terhadap data menunjukkan bahwa nilai $t_{\text {hitung }}$ yaitu sebesar 2,481 sedangkan nilai $t_{\text {tabel }}$ yaitu sebesar 2,02809 sehingga dapat diketahui bahwa $t_{\text {hitung }}$ lebih besar daripada $t_{\text {tabel. }}$. Selanjutnya nilai signifikansi $t$ yang diperoleh pada penelitian 
ini adalah 0,018 lebih kecil dari nilai sigifikansi alpha 5\% atau 0,05. Maka dapat disimpulkan bahwa temuan audit berpengaruh terhadap tingkat pengungkapan laporan keuangan Kementerian. Hasil ini sejalan dengan penelitian yang telah dilakukan sebelumnya oleh Martani dan Liestiani (2008) serta Sari et al et al. (2015) yang menyatakan bahwa temuan audit memiliki pengaruh positif terhadap tingkat pegungkapan laporan keuangan. Hal ini terjadi karena adanya upaya perbaikan yang dilakukan oleh Kementerian atas temuan audit tahun lalu agar tidak terjadi lagi pada periode berikutnya sehingga tingkat pengungkapan laporan keuangan menjadi tinggi (Sari et al et al, 2015). Akan tetapi hasil penelitian ini tidak sejalan dengan penelitian yang telah dilakukan oleh Hilmi (2012) dan Khasanah (2014) yang menyatakan bahwa temuan audit tidak mempengaruhi pengungkapan laporan keuangan. Serta penelitian lainnya yang dilakukan oleh Hendriyanti (2015) juga menyatakan bahwa temuan audit tidak berpengaruh terhadap tingkat pengungkapan informasi laporan keuangan.

Pengaruh Tindak Lanjut Hasil Pemeriksaan terhadap Tingkat Pengungkapan Laporan Keuangan Kementrian. Pengujian terhadap data yang diteliti menunjukkan bahwa nilai $t_{\text {hitung }}$ yaitu sebesar 3,612 sedangkan nilai $t_{\text {tabel }}$ yaitu sebesar 2,02809 sehingga dapat diketahui bahwa $t_{\text {hitung }}$ lebih besar daripada $t_{\text {tabel }}$. Selanjutnya nilai signifikansi t yang diperoleh pada penelitian ini adalah 0,001 lebih kecil dari nilai sigifikansi alpha 5\% atau 0,05. Maka dapat disimpulkan bahwa tindak lanjut hasil pemeriksaan berpengaruh terhadap tingkat pengungkapan laporan keuangan Kementerian. Tindak lanjut hasil pemeriksaan ini juga diungkapkan dalam laporan keuangan kementerian untuk melihat bagaimana kementerian menindaklanjuti setiap temuan yang ditemukan pada saat pemeriksaan. Tindak lanjut yang dilakukan oleh kementerian sesuai dengan rekomendasi yang diberikan oleh BPK akan meningkatkan pengungkapan laporan keuangan kementerian karena kementerian akan selalu melakukan upaya perbaikan yang sesuai dengan yang direkomendasikan. Sehingga pengungkapan laporan keuangan akan terus meningkat setiap tahunnya karena rekomendasi yang diberikan oleh BPK setelah pemeriksaan yang langsung ditindaklanjuti oleh kementerian akan meningkatkan pengungkapan laporan keungan periode berikutnya. Hasil penelitian ini sejalan dengan penelitian yang telah dilakukan sebelumnya oleh Sari et al (2015) yang menyatakan bahwa tindak lanjut hasil pemeriksaan memiliki pengaruh positif terhadap tingkat pegungkapan laporan keuangan. Dimana menurut Sari et al (2015) semakin banyak rekomendasi Badan Pemeriksa Keuangan yang ditindaklanjuti sesuai rekomendasi akan meningkatkan kualitas laporan keuangan Kementerian. Tetapi hasil penelitian ini tidak sejalan dengan penelitian Tresnawati dan Nelly (2016) yang menyatakan bahwa tindak lanjut hasil pemeriksaan tidak berpengaruh terhadap tingkat pengungkapan laporan keuangan kementerian.

Pengaruh Temuan Audit dan Tindak Lanjut Hasil Pemeriksaan terhadap Tingkat Pengungkapan Laporan Keuangan Kementrian. Hasil pengujian menunjukkan variabel temuan audit dan tindak lanjut hasil pemeriksaan berpengaruh secara signifikan terhadap tingkat pengungkapan laporan keuangan. Berdasarkan nilai signifikansi sebesar 0,001 lebih kecil dari 0,05 sehingga dapat disimpulkan bahwa temuan audit dan tindak lanjut hasil pemeriksaan berpengaruh terhadap tingkat pengungkapan laporan keuangan kementerian. Pemeriksaan yang dilakukan BPK tidak hanya semata-mata pemeriksaan keuangan yang menghasilkan opini atas kewajaran laporan keuangan. Tetapi BPK juga melakukan pemeriksaan terhadap kinerja pemerintah serta pemeriksaan dengan tujuan tertentu. Semua pemeriksaan yang dilakukan oleh BPK akan menghasilkan temuan yang berisikan kelemahan-kelemahan serta ketidakpatuhan entitas pemerintahan terhadap peraturan perundangan yang berlaku. Atas temuan tersebut, BPK juga menyampaikan rekomendasi yaitu saran terkait bagaimana langkah-langkah yang dapat dilakukan oleh entitas untuk memperbaiki kelemahan dan ketidakpatuhan yang telah terjadi tersebut (Puspitasari, 2017). Selain itu, BPK juga melakukan pemantauan tindak lanjut apakah rekomendasi sudah dilakukan dengan baik oleh pemerintah pusat, pemerintah daerah maupun kementerian dan lembaga negara.
Disclosure Level of

Financial

Statement

221 
Disclosure Level of

Financial

Statement

222
Pada prinsipnya seluruh temuan audit yang ada akan menghasilkan Rekomendasi Tindak Lanjut (RTL) yang diiringi dengan tindak lanjut hasil pemeriksaan (TLHP). Maka, baik rekomendasi tindak lanjut maupun tindak lanjut hasil pemeriksaan memainkan peran penting dalam kaitannya terhadap realisasi tugas pemeriksaan, karena paling tidak dapat menjadi tolak ukur sebuah keberhasilan tugas di lapangan (Fokus Pengawasan, 2006, p.15).

Tanpa adanya tindak lanjut hasil pemeriksaan, temuan audit dapat dikatakan sia-sia karena setiap temuan audit harus diikuti oleh tindak lanjut hasil pemeriksaan. Karena dengan dilakukannya tindak lanjut hasil pemeriksaan atas temuan yang ditemukan dalam proses audit akan meningkatkan kualitas laporan keuangan. Kualitas laporan keuangan yang baik direpresentasikan dari tingkat pengungkapan yang tinggi. Semakin tinggi tingkat pengungkapan laporan keuangan maka akan semakin baik kualitas laporan keuangan sebaliknya apabila tingkat pengungkapan laporan keuangan rendah maka kualitas laporan keuangan pun dinilai kurang baik. Selain itu, semakin tinggi tingkat pengungkapan laporan keuangan akan berpengaruh terhadap peluang opini yang diperoleh Kementerian menjadi semakin baik (Sari et al, 2015).

\section{PENUTUP}

Berdasarkan hasil pengolahan data diperoleh hasil yang menyatakan bahwa:

1. Variabel temuan audit berpengaruh signifikan terhadap tingkat pengungkapan laporan keuangan. Yang berarti bahwa banyak atau sedikitnya jumlah temuan audit mempengaruhi tinggi rendahnya tingkat pengungkapan laporan keuangan. Hal ini terjadi karena temuan yang didapat dari proses pemeriksaan laporan keuangan atau audit diungkapkan dalam laporan keuangan sesuai dengan ketentuan yang berlaku. Selain itu adanya upaya perbaikan yang dilakukan oleh Kementerian atas temuan audit tahun lalu agar tidak terjadi lagi pada periode berikutnya juga dapat meningkatkan pengungkapan laporan keuangan menjadi tinggi.

2. Variabel tindak lanjut hasil pemeriksaan berpengaruh signifikan terhadap tingkat pengungkapan laporan keuangan. Hal ini terjadi adanya upaya perbaikan yang dilakukan oleh Kementerian dengan menindaklanjuti rekomendasi yang diberikan oleh Badan Pemeriksa Keuangan (BPK). Tindak lanjut yang dilakukan oleh kementerian akan meningkatkan pengungkapan laporan keuangan pada periode berikutnya sehingga tingkat pengungkapan setiap tahunnya bertambah.

3. Variabel temuan audit dan tindak lanjut hasil pemeriksaan berpengaruh signifikan terhadap tingkat pengungkapan laporan keuangan. Temuan mengenai pelanggaran terhadap ketentuan yang berlaku baik mengenai pengendalian internal maupun kepatuhan pada peraturan undang-undangan yang ditemukan oleh auditor pada waktu pemeriksaan wajib di tindaklanjuti oleh kementerian tersebut. BPK akan memberikan rekomendasi kepada kementerian dan dari rekomendasi tersebut kementerian dapat menindaklanjuti temuan yang ada. Sehingga dari tindak lanjut yang dilakukan oleh kementerian tersebut akan meningkatkan kualitas laporan keuangan. Kualitas laporan keuangan dapat tercermin dari semakin tinnginya tingkat pengungkapan pada laporan keuangan.

\section{DAFTAR PUSTAKA}

Agusti, A.F. 2014. Faktor determinan akuntabilitas dan transparansi kementerian/lembaga. Tesis, Fakultas Ekonomi, Universitas Indonesia, Depok.

Andriani, Evanti. 2012. Pengaruh Opini Audit dan Temuan Audit Terhadap Tingkat Pengungkapan Pada Laporan Keuangan Pemerintah Daerah. Skripsi Universitas Indonesia.

Arens, Alvin A. dan James K. Loebbecke. 1991. Auditing, An Integrated Approach. Englewoods Cliff, New Jersey: Prentice Hall. 
Dwiputrianti, S. (2008). Efektivitas laporan hasil temuan pemeriksaan dalam mewujudkan reformasi transparansi fiskal dan akuntabilitas sektor publik di Indonesia. Jurnal Ilmu Administrasi, Vol. V, No. 4.

Ernawati, T. 2016. Pengaruh Ukuran Pemerintah Daerah, Jumlah SKPD, Umur Pemerintah Daerah Dan Temuan Audit Terhadap Tingkat Pengungkapan Laporan Keuangan Pemerintah Daerah (LKPD). Doctoral dissertation, Universitas Muhammadiyah Surakarta.

Evans, J. H. And Patton, J. M. 1987. Signaling and monitoring in public sector accounting. Journal of Accounting Research 25 (suppl): 130-158.

Ghozali, I. (2013). Aplikasi analisis multivariate dengan program IBM SPSS 21. Semarang: Badan Penerbit Universitas Diponegoro.

Giroux, G. 1989. Political Interest and Governmental Accounting Disclosure. Journal of Accounting and Public Policy. Vol.6, 169-83.

Hadi, Waskito. 2008. "Beyond The Call OfDuty, Good Governance Bukanlah Mimpi Belaka". 2018. "62 Tahun BPK RI Bekerjasama Mendorong Transparansi dan Akuntabilitas Keuangan Negara". Dalam Majalah Pemeriksa Bebas dan Objektif. Jakarta: Biro Humas dan Luar Negeri Badan Pemeriksa Keuangan Republik Indonesia.

Hilmi, A. Z., dan Martani, D. 2012. Analisis Faktor-Faktor yang Mempengaruhi Tingkat Pengungkapan Laporan Keuangan Pemerintah Provinsi. Simposium Nasional Akuntansi XV. Banjarmasin.

Ingram, R. W. 1984. Economics Incentives and the Choice of State Government Accounting Practices. Journal of Accounting Research. Vol. 22. No. 1. pp 126-144.

Lesmana, Sigit Indra. 2010. Pengaruh Karakteristik Pemerintah Daerah Terhadap Tingkat Pengungkapan Wajib Di Indonesia. Tesis Fakultas Ekonomi Universitas Sebelas Maret. Surakarta.

Liestiani, A. 2008. Pengungkapan Laporan Keuangan Pemerintah Daerah Kabupaten/Kota di Indonesia untuk Tahun Anggaran 2006. (Skripsi). Akuntansi FE, Universitas Indonesia, Depok.

Liu, J., and Lin, B. 2012. Government Auditing and Corruption Control: Evidence from China's Provincial Panel Data. China Journal of Accounting Research, vol. 5, pp. 163- 186.

Mahpiansyah. 2016. Dampak Tindak Lanjut Dan Ukuran Audit Terhadap Kualitas Audit. Jurnal Tata Kelola \& Akuntabilitas Keuangan Negara, Vol. 2, No. 2, 195-211.

Martani, Dwi dan Liestiani, Annisa. 2008. Disclosure of Local Government Financial Statement in Indonest. Accounting Department University Of Indonesia.

Masyitoh, R.D., Wardhani, R. \& Setyaningrum, D. 2015. Pengaruh Opini Audit, Temuan Audit, Dan Tindak Lanjut Hasil Pemeriksaan Terhadap Persepsi Korupsi Pemerintah Daerah Tingkat II Tahun 2008-2010. Simposium Nasional Akuntansi XVIII. Medan

Murgiarty, L., Ritchi, H. \& Pratama, A. 2017. Pengaruh Tindak Lanjut Hasil Pemeriksaan, Kompetensi Sumber Daya Manusia dan Pemanfaatan Teknologi Informasi Terhadap Kualitas Laporan Barang Milik Negara (Survey pada Direktorat Jenderal Sumber Daya Air, Kementerian Pekerjaan Umum dan Perumahan Rakyat). Jurnal Akuntansi Maranatha, Vol. 10, No. 2, 261-274

Murwanto, Rahmadi, dkk. 2007. Audit Sektor Publik: Suatu Pengantar Bagi Pembangunan Akuntabilitas Instansi Pemerintah. Lembaga Pengkajian Keuangan Publik dan Akuntansi Pemerintah Badan Pendidikan dan Pelatihan Keuangan Departemen Keuangan RI

Nasution, Anwar. 2009. Perbaikan Pengelolaan Keuangan Negara Dalam Era Reformasi. Badan Pemeriksa Keuangan : Dialog Publik Manado 2

Nor, W., Hudaya, M. \& Novriyandana, R. 2019. Financial statements disclosure on Indonesian local government websites A quest of its determinant(s). Asian Journal of Accounting Research, Vol. 4, No. 1, 112-128
Disclosure Level of

Financial

Statement

223 
Disclosure Level of

Financial

Statement

224

Nuswandari, Cahyani. 2009. Pengungkapan Pelaporan Keuangan Dalam Perspecrtif Signalling Theory. Kajian Akuntansi, Februari 2009, Hal 48-57. Fakultas Ekonomi Universitas Stikubank.

Oktofan, M. Sandy. 2017. Analisis Pengaruh Temuan Audit Dan Tindak Lanjut Rekomendasi Hasil Pemeriksaan Atas Opini Bpk (Studi Empiris Pada Kementerian/Lembaga Tahun 2013-2015). Skripsi Akuntansi Fakultas Ekonomi dan Bisnis, Universitas Lampung, Bandar Lampung.

Puspitasari, Pipit Siti Jenar \& Ratmono, Dwi. 2017. Analisis Faktor-Faktor Yang Mempengaruhi Tingkat Penyelesaian Tindak Lanjut Rekomendasi Hasil Pemeriksaan Bpk Ri Pada Pemerintah Daerah Di Pulau Jawa Dan Bali. Jurnal Akuntansi Diponegoro. Vol. 6 No. 1.

Rahmayanti, Dina. 2018. Determinan Tingkat Pengungkapan Laporan Keuangan Pemerintah Provinsi Di Indonesia. Skripsi. Universitas Islam Indonesia.

Rai, I Gusti Agung. 2008. Audit Kinerja pda Sektor Publik. Jakarta : Salemba Empat

Robbins, W., dan Austin. K. R 1986. Disclosure Quality in Governmental Financial Reports: An Assessment of the Appropriateness of a Compound Measure. Journal of Accounting Research. Vol. 24 No. 2

Santoso, Singgih.2010. Statistik Parametrik, Konsep dan Aplikasi dengan SPSS. Cetakan Pertama, PT Elex Media Komputindo, Jakarta. PT Gramedia. Jakarta.

Sari et al, A.P., Martani, D \& Setyaningrum, D. 2015. Pengaruh temuan audit, tindak lanjut hasil pemeriksaan dan kualitas sumber daya manusia terhadap opini audit melalui tingkat pengungkapan laporan keuangan kementerian/lembaga. Simposium Nasional Akuntansi XVIII. Medan

Setyaningrum,D. 2015. Kualitas Auditor, Pengawasan Legislatif, Dan Pemanfaatan Hasil Audit Dalam Akuntabilitas Pengelolaan Keuangan Daerah. (Disertasi). Program Pascasarjana Ilmu Akuntansi, Universitas Indonesia, Depok.

Sugiyono, Prof., Dr. 2007. Metode Penelitian Bisnis. CV Alfabeta. Bandung.

Tresnawati, Fera dan R. Nelly Nur Apandi. 2016. Pengaruh Tindak Lanjut Hasil Pemeriksaan Terhadap Kualitas Laporan Keuangan Dengan Tingkat Pengungkapan Laporan Keuangan Sebagai Variabel Moderating (Studi Empiris Pada Kementerian/Lembaga Republik Indonesia). Jurnal Aset, Vol. 8, No. 1, 13-24.

Umar, H. 2012. Pengawasan untuk Pemberantasan Korupsi. Jurnal Akuntansi dan Auditing, Vol. 8, No. 2, 95-189.

Undang-Undang Nomor 15 tahun 2004 tentang Pemeriksaan Pengelolaan dan Tanggung Jawab Keuangan Negara.

Undang-Undang Nomor 17 Tahun 2003 tentang Keuangan Negara.

Utary, Anis Rachma dan Muhammad Ikbal. 2014. Audit Sektor Publik. Yogyakarta : Interpena

Van Gansberghe, C.N. 2005. Internal auditing in the public sector: a consultative forum in Nairobi, Kenya, shores up best practices for government audit professionals in developing nations. Internal Auditor. 62(4), 69-73.

Vermeer, T. E., Styles, A. K dan Patton, T. K. 2009. Do Local Governments Present Required Disclosures for Defined Benefit Pension Plans. Journal of Accounting and Public Policy, Vol. 31. pp. 44-68.

Winanti, B. A. 2014. Analisis pengaruh temuan dan tindak lanjut pemeriksaan BPK, legitimasi kepala daerah serta pengawasan pemerintahan terhadap opini audit LKPD 2010-2011. Skripsi Akuntansi Fakultas Ekonomi, Universitas Indonesia, Depok

Yulianingtyas, R. R. 2010. Pengaruh Karakteristik Pemerintah Daerah Terhadap Kepatuhan Pengungkapan Wajib dalam Laporan Keuangan Pemerintah Daerah (Studi Empiris pada Kabupaten / Kota di Indonesia). Skripsi. Universitas Sebelas Maret.

Zimmerman,J.L. 1977. The municipal accounting maze: an analysis of political incentive. Journal of Accounting Research 15 (suppl): 107-144. 